\title{
PENGUATAN PENDIDIKAN KARAKTER MELALUI KURIKULUM MUATAN LOKAL DI SMP MUHAMMADIYAH 2 TAMAN
}

\author{
Muhammad Arif Syaifuddin*, Eni Fariyatul Fahyuni** \\ Universitas Muhammadiyah Sidoarjo \\ *arifsyai1610@gmail.com \\ **Eni.fariyatul@umsida.ac.id
}

\begin{abstract}
Moral setbacks that occur in adolescent level students experience a significant increase, not infrequently these events occur in the world of education in Indonesia. Strengthening character education is one way to reduce the effects of moral loss on students. So that the character values must be built in accordance with religious teachings and which have been determined by the government such as religiosity, mutual cooperation, independence, national and integrity. These values can be included in school programs through the integration of intraculicular, kokulikuler and extracurricular integration. In this study focuses on strengthening the existing character education in SMP Mubammadiyah 2 Park by including character habituation through local content learning, extracurricular activities and habituation activities. So it can be ensured that all student activities are based on strengthening character education. This study uses descriptive-qualitative research which results of the research are a translation of the sources obtained in the form of written and oral data and environmental observations.
\end{abstract}

Keywords: Strengthening, Character Education, Local Content

\begin{abstract}
Abstrak: Kemunduran moral yang terjadi pada peserta didik tingkat remaja mengalami kenaikan yang signifikan, tidak jarang kejadian tersebut terjadi dalam dunia pendidikan di Indonesia. Penguatan pendidikan karakter merupakan salah satu jalan untuk mengurangi dampak-dampak dari hilangnya moral pada pelajar. Sehingga nilai karakter yang harus dibangun sesuai dengan ajaran agama dan yang telah ditentuka oleh pemerintah sepert religiusitas, gotong royong, mandiri, nasional dan integritas. Nilai-nilai tersebut dapat dimasukan pada program sekolah melalui integrasi anntar intrakulikuler, kokulikuler dan ekstrakulikuler. Pada penelitian ini berfokus pada penguatan pendidika karakter yang ada di SMP Muhammadiyah 2 Taman dengan cara memasukan pembiasaan berkarakter melalui pembelajaran muatan loka, ekstrakulikuler dan keiatan pembiasaan. Sehingga dapat dipastikan seluruh kegiatan peserta didik didasarkan pada penguatan pendidikan karakter. Penelitian ini menggunakan penelitian deskriptif-kualitatif yang hasil penelitiannya
\end{abstract}


merupakan penjabaran dari sumber yang didapatkan berupa data tulis maupun data lisan serta observasi lingkungan.

Kata Kunci: Penguatan, Pendidikan Karakter, Muatan Lokal

\section{PENDAHULUAN}

Perkembangan prilaku individu setiap peserta didik memiliki perbedaan antara satu dengan yang lain. Perkembangan dari setiapa individu dipengaruhi oleh tiga hal yaitu pembawahan dari lahir, citra diri dan lingkungan. ${ }^{1}$ Ketiga faktor tersebut mempengaruhi bagaimana individu berkembang, namun dari ketiganya faktor lingkungan sangat berperan penting membentuk karakter peserta didik. Keterlibatan lingkungan keluarga dalam hal ini orang tua dan sanak saudara tidak cukup dapat mengkontrol prilaku peserta didik. Lingkungan sekolah, petemanan dan lingkungan tempat tinggal merupakan faktor pendukung dan berperan penting dalam setiap prilaku yang akan dicontoh bahkan mempengaruhi secara langsung perkembangan moral peserta didik.

Ketika berada di lingkungan keluarga peserta didik dapat dikontrol langsung prilakunya oleh orang tua, namun tidak ketika berada di lingkungan pertemanan dan sekolah. Kedua lingkungan tersebut diluar jangkauan pengawasan orang tua yang berpotensi memberikan dampak yang tidak diinginakan terhadap perkembanagan karakter peserta didik. Pada perkembangannya sekolah formal tingkat dasar maupun menengah menggunakan sistem pembelajaran full day di sekolah. Secara tidak langsung peserta didik berada di lingkungan sekolah bersama dengan pengajar dan teman sekolah delapan jam sehari. Peran sekolah sangatlah penting sebagai benteng sekaligus tombak bagi menentukan arah moral maupun prilaku dari peserta didik.

Kualitas moral pada fase pelajar merupakan pondasi dasar menjadikan manusia yang berakhlak dan berbudi pekerti yang baik. Namun realita yang terjadi saat ini prilaku peserta didik mengalami penurunan secara moral dan akhlaq, seperti contoh siswa melakukan pelecehan terhadap guru ketika berada di sekolah. Contoh perbuatan tersebut seakan siswa tidak memiliki sopan dan santun terhadap guru yang dianggap sebagai pengganti orang tua di sekolah. Penurunan moral pesera didik

${ }^{1}$ Andi Mappiare, Psikologi Remaja (Surabaya: Usaha Nasional Surabaya, 1982). 
merambah pada pemanfaatan teknologi sosial media yang tidak tepat guna oleh siswa mengakibatkan banyak video maupun foto yang tidak layak terpublikasi di dunia maya.

Kedua contoh kasus tersebut merupakan sebagian kecil kemerosotan karakter yang dimiliki peserta didik yang terjadi pada era saat ini. Lingkungan sekolah merupakan salah satu anti tesis penurunan degradasi moral yang terjadi pada pelajar. Sebagaimana difungsikannya sekolah sebagai alat pencapaian tujuan pendidikan nasional yang tercantum dalam Undang-undang RI No 20 tahun 2003 pasal 3 yaitu membantu dan mengembangkan watak serta peradaban bangsa yang bermartabat dan cerdas dengan cara membentuk pribadi siwa yang berpontensi, beriman kepada Tuhan Yang Maha Esa, berakhlak mulia, cerdas dan bertanggung jawab. Berdasarkan tujuan pendidikan tersebut sekolah tidak cukup membekali pribadi siswa dengan kecerdasan intelektual akan tetapi kecerdasan religiusitas dengan membekali pengetahuan agama dan kepribadian yang sesuai dengan ajaran agama.

Penambahan pembelajaran agama yang terstruktur maupun yang tidak terstruktur merupakan salah satu cara untuk mengurangi sedikitnya pembelajaran agama yang diberikan di sekolah. Sesuai dengan aturan dan struktur yang dikeluarkkan oleh Kementrian Pendidikan dan Kebudayaan Republik Indonesia tentang Kurikulum 2013, sekolah hanya diberikan dua jam pembelajaran setiap minggu dalam mata pelajaran Pendidikan Agama Islam dan Budi pekerti. Perlu adanya sekolah memberikan mata pelajaran tambahan pendidikan agama dan budi pekerti sebagai penguatan karakter peserta didik.

Penguatan karakter peserta didik dapat dilakukan dengan menambahkan pembelajaran agama Islam dan budi pekerti dalam bentuk penunjang dan pembiasaan berkarater yang dimasukan dalam MULOK (muatan lokal) pada struktur kurikulum sekolah. Bentuk muatan lokal ini dapat berupa mata pelajaran maupun pembiasaan kesaharian yang mengarah pada terbentuknya pembiasaan positif sebagai upaya mengurangi dampak negatif kurangnya moral pada peserta didik. Setiap sekolah mempunyai ciri khas masing-masing dalam materi yang diberikan guna mencapai target peningkatan karakter atau moral peserta didik, salah satunya adalah SMP Muhammadiyah 2 Taman. SMP Muhammadiyah 2 Taman merupakan lembaga pendidikan Islam dibawah naungan persyarikatan Muhammadiyah yang memiliki cita- 
cita pada dunia pendidikan sejalan dengan tujuan pendidikan nasional. Sekolah tersebut memiliki visi "Berbudaya Islami. Unggul Prestasi" dengan moto "The Islamic Character School”. Dilihat dari visi dan moto sekolah tersebut dapat disimpulkan bahwa sekolah berupaya menuangkan tujuan out put peserta didiknya memiliki karakter dan moral yang baik. Program sekolah untuk menuju kearah yang diiginkan harus selaras dan mendukung upaya pesera didik menjadikan pribadi yang bermoral dan berkarakter sesuai dengan yang diinginkan.Oleh karena alam penelitian ini memfokuskan pada kurikulum muatan lokal sekolah yang digunakan untuk membantu memperkuat karakter peserta didik.

\section{METODE PENELITIAN}

Penelitian ini menggunakan metode kualitatif deskriptif yang akan menyajikan fakta yang ada dilapangan dan diperkuat dengan bukti relevan. Dalam penelitian deskriptif data ataupun sumber peneilitian dapat berupa upacapan, kata, maupun tulisan yang dapat diamati. ${ }^{2}$ Data dan sumber penelitian diambil dari sumber tulis seperti buku penunjang teori penelitian maupun pendukung yang didapatkan dari dokumen-dokumen sekolah seperti dokumen satu KTSP yang memuat tentnag kurikulum muatan local dan kegiatan sekoah serta perangkat pengajar guru yang mencantumkan tentang pengutan karakter dalam pembelajaran dan observasi langsung terhadap kegiatan-kegiatan yang dilakukan di sekolah sekolah. Data penelitian ini juga ditunjang dari wawancara dengan kepala sekolah dan guru pembina terkait dengan program kegiatan yang diteliti.

\section{KARAKTER PESERTA DIDIK}

Secara harfia moral dan karakter merupakan dua hal yang dapat disandikan sejajar dan memiliki makna yang sama. Jika moral dalam agama Islam dapat disebut sebagai akhlaqul karimah, yaitu perbuatan manuasia yang didasari sopan dan santun terhadap orang lain dalam hal berprilaku maupun berbicara. ${ }^{3}$ Sedangkan pengertian karakter adalah keinginan manusia untuk dapat melakukan yang tebaik melalui

${ }^{2}$ Nana Syaodih Sukmadinata, Metode Penelitian Pendidikan (Bandung: Remaja Rosdakarya, 2005), p. 28.

3 Abdul Karim, Islam Nusantara (Yogyakarta: Gama Media, 2013). 
prilaku, motivasi dan kemampuan dalam kehidupan sehari-hari. ${ }^{4}$ Dari beberapa pendapat diatas dapat disimpulkan bahwa karakter ataupaun moral adalah perbutan yang dilakukan oleh masing-masing individu secara terus menerus sehingga terbiasa dan didasari oleh maksud berbuat baik sesuai dengan norma yang berlaku di lingkungannya.

Karakter dapat diimplementasiakan dalam kehidupan sehari-hari setiap individu. Pembiasaan karakter tersebut akan menjadikan budaya yang tertanam pada pikiran bawah sadar. Pembentukan karakter yang paling utama adalah lingkungan keluarga, pembiasaan-pembiasaan baik dapat dicotohkan langsung oleh orang tua. Pembiasaan karakter dapat pula dilakukan di sekolah, oleh karena itu dalam dunia pendidikan dikenal dengan istilah PPK (Penguatan Pendidikan Karakter). Secara nasional pengertian pendidikan karakter adalah adalah pendidikan yang bermaksud untuk mengembangkan karakter bangsa pada peserta didik sehingga muncul pembiasaan berkarakter dan menerapkan nilai-nilai yang telah ditetapkan. ${ }^{5}$

Dunia pendidikan mengenal beberapa jenis pendidikan karakter yang sering kita temui, diantaranya adalah pendidikan karakter berbasis religius. Karakter ini menerapkan dasar-dasar agama pada setiap pelaksanaanya, sebagai contoh prilaku peserta didik sesuai dengan perintah agama. Yang kedua adalah pedidikan karakter yang berbasis pada nilai budaya, Indoesia merupakan negara yang berpedoaman pada ideology pancasila sehingga nila-nilai pancasilais tersebut sebagai pedoman dalam pelaksanaan pendidikan karakter tersebut. Pendidikan karakter berikutnya adalah berbasis lingkungan, aturan ataupun norma yang berlaku di lingkungan sekitar dijadikan sebagai panutan yang harus ditaati. Dan yang terakhir adalah pendidikan karakter berbasis potensi diri, pendidikan karaketer ini berdasarkan pada pemberdayaan potensi yang dimiliki oleh setiap individu. ${ }^{6}$

Selain itu penerapan karakter dalam pendidikan telah dicanangkan oleh Kementrian Pendidikan Nasional dan dituangkan kedalam PERMENDIKBUD no 20 tahun 2018 tentang Peguatan Pendidikan Karakter Pada Satuan Pendidikan

${ }_{4}^{4}$ Tadkirotun Musfiroh, Cerdas Melalui Bermain (Jakarta: Grafindo, 2008), p. 27.

${ }^{5}$ Kemendiknas, Pengembangan Pendidikan Budaya Dan Karakter Bangsa Pedoman Sekolah (Jakarta: Pusat Kurikulum Balitbang, 2010), p. 4.

${ }^{6}$ Yahya Khan, Pendidikan Karakter Berbasis Potensi Diri : Mendongkrak Kualitas Pendidikan (Yogyakarta: Pelangi Publishing, 2010), p. 4. 
Formal. Dalam aturan tersebut karakter yang harus dibangun dan diajarkan kepada peserta didik adalah religius, toleransi, disiplin, bekerja keras, kreatif, mandiri, demokratis, rasa ingin tahu, semangat kebangsaan, cinta tanah air, menghargai prestasi, komunikatif, cinta damai, gemar membaca, peduli lingkungan, peduli sosial dan bertannggung jawab. Dari 18 karakter tersebut dikelompokkan menjadi lima nilai karakter yang diturunkan dari ideologi pancasila. Kelima karakter tersebut adalah religius, nasionalisme, integritas, kemandirian dan kegotongroyongan. Religius merupakan nilai yang diambil berdasarkan kepercayaan kepada Tuhan Yang Maha Esa diwujudkan dengan melaksanakan ajaran sesuai dengan agama yang dianut. Pengamalan nilai religius juga diterapkan dengan bertoleransi terhadap penganut agama yang lain. Sedangkan nilai nasionalisme adalah cara berfikir, bersikap dan berbuat dengan mendahulukan kelompok lain dari pada kepentingan pribadi maupun kelompok individu. Bentuk lain dari nasionalisme ini adalah menunjukan kesetiaan terhadap bangsa dan negara dengan menghargai bahasa, sosial, politik, budaya yang ada. $^{7}$

Nilai integritas yang dimaksudkan diatas merupakan perwujudan pribadi yang mempunyai tanggung jawab dan mampu melaksanakan amanah yang diberikan. Nilai karakter yang keempat adalah mandiri, diharapkan setiap individu mampu mencurahkan segala kemampuan untuk menggapai harapan yang dicanangkan serta menjadi pribadi yang memiliki etos kerja tinggi. Nilai yang terakhir adalah gotong royong, nilai ini mencerminkan perbuatan kerjasama dalam melaksanakan dan menyelesaikan persoalan. Dalam nilai gotong royong dimaksudkan pula siswa mampu menghargai sesama, berkomitmen dan memiliki rasa solidaritas.

Dapat disimpulkan bahwa karakter yang harus diperkuat dan diberikan kepada peserta didik adalah kelima karakter yang telah dicanangkan oleh Kementrian Pendidikan Nasional. Tinggal bagaimana sekolah dapat memasukan kelima nilai karakter tersebut dalam proses pembelajaran di sekolah. Sesuai dengan anjuran Menteri Pendidikan penguatan pendidikan karakter dapat dimasukan dengan mengintegrasikan anatara pembelajaran intrakulikuler, ekstrakulikuler dan

\footnotetext{
${ }^{7}$ Isa Anshori and others, 'Penguatan Pendidikan Karakter Di Madrasah Isa Anshori Universitas Islam Negeri Sunan Ampel Surabaya. Jl. Ahmad Yani No.117. Jemur Wonosari. Surabaya', 1.2 (2017), 63-74 <https://doi.org/10.21070/halaqa.v1i2.1243>.
} 
kokulikuler. Bentuk penguatan karakter pada intrakulikuler dengan dimasukanya muatan-muatan karakter kedalam rencana pembelajaran yang telah disiapkan oleh guru pengajar di kelas. Setiap guru juga dapat memasukan nilai karakter ketika proses pembelajaran dalam bentuk metode pembelajaran atupun ketika akan memulai dan mengakhiri pembelajaran.

Penguatan karakter melalui kokulikuler dan ekstrakulikuler dapat dituangkan kedalam pelajaran muatan lokal sekolah. Sekolah diberi kebebasan dalam menentukan muatan lokal yang akan diajarkan kepada peserta didiknya sesuai dengan kebutuhan. Pembahasan penelitian ini mengarah pada muatan lokal sekolah yang mendukung terbentuknya penguatan pendidikan karakter di sekolah.

\section{MUATAN LOKAL}

Dasar pemikiran kurikulum muatan lokal merupakan pertimbangan dari wilayah negara Republik Indonesia yang terdiri dari berbagai macam suku, bahasa dan merupakan negara kepulauan yang sangat luas. Dengan luas dan keanekaragaman bangsa Indonesia inilah perlunya Kementrian Pendidikan Republik Indonesia memberiakan keleluasaan pada setiapa lembaha pendidikan di setiap daerah untuk mengembangkan potensi lokalnya masing-masing. Deskripsi muatan lokal di ambil dari Pusat Kurikulum Balitbang Depdiknas adalah pembelajaran kulikuler yang disesuaikan dengan keunggulan dan potensi yang dimiliki setiap daerah yang sehingga dijadikan sebagai ciri khas pada sekolah tersebut sehingga diterapkan menjadi mata pelajaran di sekolah. ${ }^{8}$ Muatan lokal juga dapat diartikan sebaga pembelajaran yang disesuaikan dengan keadaan dan kebutuhan masing-masing sekolah sebagai penunjang dalam mencapai tujuan sekolah. ' Jika ditilik dari pendapat Mulyasa dan pengertian muatan lokal dari Pusat Kurikulum Depdiknas Republik Indonesia muatan lokal dalam pembelajaran sekolah dapat dimasukan ke dalam Kurikulum Tingkat Satuan Pendidikan yang disesuaikan dengan kebutuhan sekolah.

\footnotetext{
${ }^{8}$ Balitbang Depdiknas Pusat Kurukulum, Model Pengembangan Pelajaran Muatan Lokal SD/MI/SDLBSMP/MTS-SMPLB-SMA/MA/SMALB/SMK (Jakarta: Depdiknas, 2007).

${ }^{9}$ E Mulyasa, Kurikulum Tingkat Satuan Pendidikan: Sebuab Panduan Praktis (Bandung: Remaja Rosdakarya, 2009).
} 
Dalam tujuan pelaksanaan muatan lokal dalam pembelajaran di sekolah di bagi menjadi dua, yaitu tujuan secara langsung dan tujuan tidak langsung. Tujuan langsung dalam muatan lokal yaitu memanfaatkan dan menggunakan potensi yang ada di sekitar sekolah guna menambah pengetahuan dan ketrampilan siswa. Sedangkan tujuan tidak langsung adalah sebagai dampak dari pembelajaran muatan lokal yang diberikan ke peserta didik sehingga menjadi pembiayasaan positif seharihari. ${ }^{10}$ Selaras dengan Abdullah, tujuan muatan lokal menurut Pusat Kurikulum adalah (1) mendekatkan peserta didik dengan lingkungan, sosial dan budaya sekitar; (2) mengenali dan memahami potensi yang ada dalam lingkungan pesera didik; (3) menunjukan sikap sesuai dengan budaya dan norma yang berlaku dalam lingkungannya dan (4) dapat menyelesaikan masalah yang berkembang di lingkungan masyarakat. Menurut pengertian dan tujuan muatan lokal diatas pelaksanaa pembelajaran dan isi pembelajaran dikembalikan kepada sekolah. Sekolah harus mampu mengamati kepentingan yang harus dipenuhi untuk mengatasi masalah yang berkembang di masyarakat dan lingkungan di sekitar sekolah maupun peserta didik.

Perkembangan zaman merupakan salah satu aspek yang harus di perhatiakan pula dalam pelaksanaan muatan lokal. Budaya dan kebiasaan dalam masyrakat akan terus berubah sesuai dengan perkembangan zaman. Sebagai contoh hilangnya sopan santun yang ada pada pembiasaan kesariaan yang tidak ditemukan pada sepuluh tahun lalu. Bagaimana sekolah mampu memfasiltasi perubahan budaya yang ada pada peserta didik. Sebagaimana penjabaran fungsi dari kurikulum muatan lokal adalah sebagai fungsi penyesuaian, fungsi integrasi dan fungsi perbedaan. Fungsi penyesuaian dalam muatan lokal adalah upaya sekolah mampu menyesuaikan pembiasan yang terjadi sesuai dengan budaya yang berkembang di masyrakat. Fungsi yang kedua adalah mengintegrasikan program sekolah dengan keinginan masyarakat sehingga mampu mendidik peserta didik sesuai dengan yang dibutuhkan oleh masyarakat, paling tidak mampu dan berguna ketika berada lingkungan masyarakat luas. Fungsi muatan yang terakhir adalah sebagai pembeda, yang dimaksud pembeda adalah mampu memfasilitasi keinginan sesuai dengan bakat minat peserta didik yang

10 Abdullah Idi, Pengembangan Kurikulum: Teori Dan Praktik (Jakarta: Gaya Media Pratama, 1999), p. 188. 
memliki perbedaan satu dengan yang lainya. ${ }^{11}$ Berdasarkan fungsi dari muatan lokal tersebut dapat disimpulkan bahwa penerapan muatan lokal di sekolah harus mampu mewadahi keinginan peserta didik dan tidak mengindahkan kebutuhan yang ada pada masyarakat sehingga hasil dari muatan lokal dapat berkontribusi dalam lingkungnya.

Pelaksanaan muatan lokal di sekolah pimpinan sekolah paling tidak harus mempersiapakan komponen dalam penyelenggaraanya, antara lain yaitu (1) menentukan mata pelajaran atau kegiatan yang sesuai dengan kebutuhan sekolah berdasarkan kondisi sekolah, karakteristik peserta didik dan guru pengajar; (2) mempersiapkan guru pengampuh mata pelajar yang akan diajarkan. Guru pengampuh ini dapat menggunakan guru yang sudah ada atau mengundang guru tamu sesuai dengan materi yang diberikan; dan yang ketiga adalah pendanaan dan sumber belajar. $^{12}$

Namun perlu diperhatikan pula berdasarkan PERMENDIKBUD no 20 tahun 2018 tentang penerapan penguatan pendidikan karakter dengan menggunakan muatan lokal tidak hanya memfasilitasi dari segi kognitif (olah pikir) akan tetapi harus memperhatikan spiritualitas (olah hati), estetika (olah rasa) dan juga kinestetik (olah raga). Artinya sekolah tidak hanya menggunakan pembelajaran sebagai alat untuk penguatan karakter akan tetapi dapat menggunakan program-program pembiasaan yang sesuai dengan kebutuhan dan kondisi sekolah. Dalam penjabaranya muatan lokal yang ada disekolah dijadikan salah satu upaya untuk mensukseskan penguatan pendidikan karakter.

Optimalisasi kokulikuler, ekstrakulikuler dan muatan lokal adalah upaya yang dilakukan oleh SMP Muhammadiyah dalam mewujudkan pendidikan karakter pada peserta didik. Berbagai pembelajaran mutan lokal, kegiatan kokulikuler dan ekstrakulikuler diarahkan sebagai ujung tombak penerapan PPK di sekolah. Penjabaran dan pembahasan program penguatan pendidikan karakter di sekolah kan disajikan dalam program penguatan karakter peserta didik dibawah ini.

11 Oemar Hamalik, Dasar-Dasar Pengembangan Kurikulum (Bandung: Remaja Rosdakarya, 2007), p. 266. 12 Mulyasa. 


\section{PROGRAM PENGUATAN KARAKTER PESERTA DIDIK}

Muatan Lokal yang dipilih ditetapkan berdasarkan ciri khas, potensi dan keunggulan daerah, serta ketersediaan lahan, sarana prasarana, dan tenaga pendidik. Sasaran pembelajaran muatan lokal adalah pengembangan karakter dan moral peserta didik, jiwa kewirausahaan dan penanaman nilai-nilai budaya sesuai dengan lingkungan. Nilai-nilai karakter serta moral yang dikembangkan dalam pembelajaran muatan lokal antara lain kejujuran, tanggung jawab, disiplin, kepekaan terhadap lingkungan, dan kerja sama. Selain itu nilai-nilai kewirausahaan dan budaya juga dikembangkan dalam pembelajaran muatan lokal antara lain inovasi, kreatif, berpikir kritis, eksplorasi, komunikasi, kemandirian, dan memiliki etos kerja.

Penanaman nilai-nilai tersebut diintegrasikan di dalam proses pembelajaran kulikuler di topang dengan kegiatan kokulikuler dan ekstrakulikuler serta program peningkatan karakter yang telah di susun oleh sekolah. Pelaksanaan pembelajaran muatan lokal yang dikondisikan supaya nilai-nilai tersebut dapat menjadi sikap dan perilaku dalam kehidupan sehari-hari. Pembelajaran muatan lokal peningkatan karakter yang ada di SMP Muhammadiyah 2 Taman ditunjang dengan kegiatan pengembangan diri berupa Bimbingan Konseling yang diberikan alokasi tatap muka sebanyak 1 jam pembelajaran setiap pekan. Selain itu pengembangan diri sebagai upaya penguatan karakter peserta didik berupa kegiatan ekstrakulikuler sesuai dengan minat dan bakat peserta didik serta mengutamakan kegiatan yang berhubungan dengan penguatan karakter seperti kepanduan, qiroatil Quran, seni bela diri, Palang Merah Remaja dan Pasukan Pengibar Bendera (PASKIBRA). Ekstrakulikuler diatas sebagai wujud penerapan lima nilai yang telah dicanagkan oleh pemerintah. Program penguatan karakter tidak lupa pula mencantumkan pembelajaran muatan lokal dan kokulikuler dalam kegiatan sekolah.

Pembelajaran muatan lokal dan kokulikuler yang diberikan kepada peserta didik berupa kegiatan yang terstruktur dan tidak terstruktur. Kegiatan yang terstruktur merupakan pembelajaran muatan lokal yang telah ditentukan oleh pemerintah daerah maupun persyarikatan. Sebagai contoh sesuai dengan peraturan Gubernur Jawa Timur nomor 19 tahun 2014 tentang muatan lokal pembelajaran Bahasa Daerah yang harus diajarkan kepada seluruh sekolah dilingkup provinsi Jawa 
Timur sebagai upaya pelestarian budaya dan etika serta moral sebagai budaya dan pengenalan bahasa jawa agar tidak luntur dalam penggunaan di keseharian.

Muatan lokal berikutnya sesuai dengan SK Majelis Dikdasmen PP Muhammadiyah Nomor: 98/KEP/I.4/F/2017 tentang seluruh sekolah dibawah naungan persyarikatan Muhammadiyah mulai dari jenjang Sekolah Dasar hingga Sekolah Menengah pertama dan atas wajib menggajarkan mata pelajaran tambahan Al-Islam, Kemuhammadiyahan dan Bahasa Arab. Ketiga mata pelajaran tersebut digunakan sebagai pondasi dasar seluruh pelajar di lingkungan sekolah Muhammadiyah dalam melaksanakan segala sesuatu dalam kehidupan. Dengan agama yang kuat ditopang dengan pengetahuan bahasa Arab sebagai bahasa AlQuran dan diperkuat ideologi Kemuhammadiyahan diharapkan pelajaran Muhammadiyah sebagai individu yang cerdas dan religius.

Sedangkan kokulikuler yang diberikan kepada siswa SMP Muhammadiyah adalah Baca Tulis Al-Quan (BTQ) sesuai dengan Peraturan Bupati nomor 63 tahun 2011 yang dijadikan sebagai muatan lokal. Mata pelajaran ini dimasukan kedalam kokulikuler sebagai penunjang mata pelajaran lain yaitu ISMUBA. Tabel.1 berikut akan menggambarkan struktur kegiatan dan pembelajaran pendukung penguatan pendidikan karakter di SMP Muhammadiyah 2 Taman:

Tabel.1 Susunan muatan lokal \& pengembangan diri SMP Muhammadiyah 2 Taman

\begin{tabular}{|c|l|c|c|c|}
\hline 1. & Muatan Lokal & \multicolumn{3}{|c|}{ Alokasi waktu per } \\
& & \multicolumn{3}{|c|}{ kelas } \\
\hline & Bahasa Daerah (Jawa) & 2 & 2 & 2 \\
\hline & Al Islam & 1 & 1 & 1 \\
\hline & Bahasa Arab *) & 2 & 2 & 2 \\
\hline & Semuhammadiyahan *) & 1 & 1 & 1 \\
\hline 2 & Pengembangan Diri & 2 & 2 & 2 \\
\hline & A. Bimbingan Konseling & & & \\
\hline & B. Ekstra Kurikuler & & & \\
\hline & 1. Qiro'atul Qur'an/Tilawatil Qur'an & & & \\
\hline & 2. Kepanduan Hizbul Wathan (HW) & & & \\
\hline
\end{tabular}




\begin{tabular}{|l|l|l|l|l|}
\hline & 3. Seni Bela Diri (Tapak Suci) & & & \\
\hline & 4. PMR & & & \\
\hline & 5. Paskibra & & & \\
\hline & 6. English Club & & & \\
\hline & 7. Science Club & & & \\
\hline & 8. Futsal & & & \\
\hline & 10. Masket & & & \\
\hline & 11. Marching Band & & & \\
\hline & 12. Tari Tradisional & & & \\
\hline 3 & Kokurikuler & & & \\
\hline & Baca Tulis Al-Qur'an (BTQ) & & & \\
\hline & Jumlah & $\mathbf{1 0}$ & $\mathbf{1 0}$ & $\mathbf{1 0}$ \\
\hline
\end{tabular}

Program pada tabel diatas merupakan pembelajaan muatan lokal dan kokulikuler dan ekstrakulikuler yang diselenggarakan di sekolah sebagai upaya melaksanakan penguatan karakter pada lingkungan sekolah. Penulis berusaha menjabarkan hubungan anatara program-program sekolah dengan nilai-nilai karakter yang telah ditentukan oleh pemerintah. Dalam penjabaran ini pula akan ditambahkan kegiatan pembiasaan yang telah diprogramkan oleh sekolah dalam keseharian sebagai penunjang ketiga kegiatan yang ada di sekolah.

Penjabaran tentang muatan Lokal yang diselenggarakan di SMPMuhammadiyah 2 Taman adalah Bahasa Daerah, Baca Tulis Al-Qur'an (BTQ), Bahasa Arab, Kemuhammadiyahan dan Student Islamic Lesson (SIL) sebagai berikut: 1. Muatan Lokal Bahasa Daerah (Jawa)

Muatan lokal yang diajarkan sebagai penguatan karakter peserta didika yang pertama adalah Bahasa Daerah, mata pelajaran ini mengajarkan tentang etika, estetika, moral, spiritual dan karakter yang tertanam pada masyarakat suku jawa khususnya Jawa Timur. Disamping itu pelaksanaan mata pelajaran Bahasa daerah bertujuan untuk melestarikan, mengembangkan, dan mengkreasikan bahasa dan sastra daerah khususnya bahasa Jawa. 
2. Muatan Lokal Baca Tulis Al-Qur'an (BTQ)

Baca Tulis Al-Quran ini merupakan salah satu kokulikuler yang diajarkan kepada peserta didik di semua jenjang. Tujuan diajarkannya BTQ sebagai penunjang pembelajaran dalam mata pelajaran agama lainya, karena materi yang diajarkan dalam BTQ ini adalah memperlancar membaca ayat suci Al-Quran, mengenalkan cara menulis huruf hijaiyah hingga sebagai pembiasaan untuk membaca Al-quran setiap hari.

Pembelajaran BTQ di SMP Muhammadiyah 2 Taman memiliki beberapa jenjang sesuai dengan kemampuan peserta didik dalam membaca Al-Quran. Jenjang pertama adalah pengenalan dan cara membaca huruf hijaiyah, pada fase ini peserta didik diajarkan tentang dasar bacaan dan panjang-rendah bacaan dalam membaca $\mathrm{Al}$ Quran. Jenjang yang kedua adalah Tajwid, setealh peserta didik paham dan bisa melafadzakn huruf hijaiyah dengan baik dan benar tahap selanjutnya peserta didik diajarkan tentang hukum bacaan dalam membaca Al-Quran. Dan yang terakhir adalah jenjang Hifdzil Quran, pada jenjang tertinggi ini bagi peserta didik yang telah mampu membaca dengan menggunkan hukum bacaan dengan baik dan benar maka peserta didik dapat melanjutkan dengan menghafal surat-surat dalam Al-Quran sesuai dengan petunjuk para guru. Dari kegiatan BTQ ini peserta didik diajarkan tentang aspek karakter religiusitas dengan selalu mendekatkan diri dengan Tuhan Yang Maha Esa.

3. Muatan Lokal ISMUBA (Al-Islam, Kemuhammadiyahan dan Bahasa Arab)

Mata Pelajaran ISMUBA pada sekolah Muhammadiyah merupakan ciri khusus yang tidak dimiliki lembaga pendidikan lainya. ISMUBA merupakan satu kesatuan pembelajaran yang mengajarkan tentang Al-Islam, Kemuhammadiyahan dan Bahasa Arab. Penambahan pelajaran agama seperti Al-Islam merupakan keresahan yang terjadi karena jumlah jam perpekan Pendidikan Agama Islam tidak mencukupi untuk menanamkan rasa religius pada peserta didik. Materi yag diajarkan pada mata pelajaran Al-Islam meliputi Aqidah, Akhlaq, Quran-hadist, Tarikh (sejarah Islam) dan fikih. Sedangkan mata pelajaran Kemuhammadiyahan merupakan pengetahuan tentang ideologi persyarikatan Muhammadiyah yang harus diajarkan kepada peserta didik. Tidak cukup tentang sejarah berdirinya Muhammadiyah dan pedoman yang diikuti oleh warga Muhammadiyah namun materi pembelajaran ini juga mengajarkan 
tentang cara pandang dan bertindak seperti yang pernah di contohkan oleh pendirinya K.H Ahmad Dahlan, seperti aspek religius, gotong royong, saling menghargai, menjadi individu yang cerdas, berintegritas dan lain-lain. Dan yang terakhir adalah mata pelajaran Bahasa Arab, lazimnya Bahasa Arab banyak diajarkan di sekolah yang berafilisai dengan pondok pesantren namun seluru sekolah Muhammadiyah mengajarkanya mulai dari sekolah dasar hingga tinggi dengan anggapan bahwa Bahasa Arab merupakan bahasa yang digunakan dalam Al-Quran sehingga akan mempermudah memahami Al-Quran jika mengerti bahasa yang digunakan.

Ke-khasan pada ketiga materi tersebut implementasi dari tujuan pendidikan Muhammadiyah sebagai lembaga pendidikan yang menerapkan pendidikan integratifholistik. Pendidikan integratif-holistik adalah pendidikan yang mengajarkan satu kesatuan antara pendidikan agama dan pendidikan umum begitupula sebaliknya pendidikan umum dan pendidikan agama. Dalam penyusunan kurikulum ISMUBA ini pula menerapkan prinsip-prinsip sebagaimana berikut: ISMUBA sebagai upaya peningkatan Iman, Takwa dan Akhlak Mulia, Kebutuhan kompetensi masa depan, ISMUBA diguunakan untuk meningkatkan potensi, kecerdasan dan kemampuan peserta didik, mempertimbangkan keragaman potensi dan karakteristik lingkungan sekitar, ISMUBA digunakan sebagai pendamping dalam dunia pendidikan dan dunia kerja ${ }^{13}$. Berdasarkan prinsip dasar terbentuknya mata pelajaran ISMUBA tujuan dari pembelajaranya adalah menciptakan manusia yang beriman dan bertakwa serta memiliki akhlak yang mulia serta mencadikan pribadi yang cerdas siap terjuan dalam masyrakat.

4. Muatan Lokal Student Islamic Lesson

Muatan lolak yang terakhir yang diajarkan di SMP Muhammadiyah 2 Taman adalah SIL (Student Islamic Lesson). Mata pelajaran ini masuk dalam kegitan intrasekolah yang diberikan waktu dua jam pelajaran per pekan. Upaya itu dilakukan karena sebagai upaya penerapan dari visi sekolah yang mengarah pada Berbudaya Islami.Pembalajaran pada mata pelajaran ini mengacu pada penerapan hafalan siswa. Diharapkan output siswa setelah mempelajari SIL dapat menghafal dan menerapkan

${ }^{13}$ Majelis Pendidikan Dasar dan Menengah Pimpinan Pusat Muhammadiyah, Kurikulum Pendidikan AlIslam, Kemuhammadiyahan Dan Bahasa Arab (ISMUBA) (Jakarta, 20017). 
tentang Do’a Sholat, Dzikir setelah Shalat, do'a Shalat Dhuha, hafal minimal Juz 30, Doa sehari-hari, Surah Al-Quran pilihan dan Hadist pilihan.

Diharapakan dari hasil pembelajaran ini adalah menghasilkan peserta didik yang berkarakter dan berbudaya Islami sesuai dengan visi sekolah. Dan peserta didik mampu menularkan karakter-karakter yang baik ketika berada di masyarkat sesuai dengan kaidah agama Islam yang dipelajari.

Selain Muatan lokal dan pelajaran kokulikuler yang diberikan kepada peserta didik sebagai upaya dalam penguatan pendidikan karakter, SMP Muhammadiyah 2 Tamann juga memilliki program penunjang lain dalam bentuk pengembangan diri siswa dan kegiatan peningkatan karakter yang telah disiapakan oleh sekolah. Pengembangan diri siswa yang dimaksud adalah Bimbingan konseling dan penyuluhan siswa serta kegiatan ekstrakulikuler yang mengarah pada penguatan karakter. Sedangkan kegiatan peningkatan karakter disekolah dapat berupa pembiasaan beribadah dan kegiatan penunjang lainya. Penjabaran tentang program dan kegiatan penguatan karakter sebagai berikut:

1. Bimbingan Konseling dan Penyuluhan

SMP Muhammadiyah 2 Taman mewadahi bagi peserta didik untuk dapat menemukan jati diri melalui bimbingan dan konseling yang dilakukan oleh guru $\mathrm{BP} / \mathrm{BK}$ yang ada di sekolah. selain sebagai pendamping dan koselor guru BP/BK di sekolah memilliki tugas dan fungsi kepada peserta didik sebagai berikut (1) memberikan pemahaman kepada peserta didik terkait dengan pribadi dirinya dan lingkungan sekitarnya; (2) menjadi fasilitator pertumbuhan dan perkembangan jiwa dan mental peserta didik; (3) membantu menyesuaikan diri sendiri di masa perkembangan dengan lingkungan sekitarny; (4) memberikan gambaran tentang masa depan penddikan, pekerjaan dan karir; (5) guru BP/BK merupakan ujung tombak dalam mencegah timbulnya permasalahan yang dan menyelesaikan masalah jika terjadi masalah antar peserta didik di sekolah; (6) guru BP/BK juga memastikan lingkungan sekolah kondusif sebagai tempat berkembangnya peserta didik; dan yang terkahir adalah membantu peserta didik menemukan potensi yang dimiliki sesuai dengan minat dan bakat setiap individu ${ }^{14}$.

${ }^{14}$ Heru Mugiarso, Bimbingan Dan Konseling (Semarang: Unnes Press, 2011). 
Berdasarkan tujuan dan fungsi Bimbingan konseling dan penyuluhan diatas penting adanya bimbingan yang diberikan kepada peserta didik sebagi proses berkembangnya individu yang berkarakter. Guru bimbingan konseling dan penyuluhan yang ada di SMP Muhammadiyah 2 Taman benar-benar ditugaskan dan mendampingi peserta didik dan menyiapkanyanya menjadi pribadi yang berkarakter. Dalam prosesnya seluruh karakter yang ada dalam pendidikan penguatan karakter menjadi ranah yang harus dikembangkan dalam penanganan guru $\mathrm{BP} / \mathrm{BK}$.

2. Ekstrakulikuler

Pengembangan diri melalui kegiatan ekstrakulikuler merupakan salah satu cara yang dapat dilakukan dalam pengiatan karakter peserta didik. Kelima golongan dalam pendidikan penguatan karakter yaitu religius, integritas, nasionalis, gotong royong dan mandiri dapat dicapai melalui pelaksanaan ekstrakulikuler di sekolah. Sekolah menyediakan 12 jenis ekstrakulikuler yang terdiri dari empat kecakapan hidup yaitu akademik, kesenian, olahraga dan ketrampilan. Kegiatan ekstrakulikuler bidang akademik menekankan rasa ingin tau dan memiliki integritas atau semangat dalam berprestasi serta mengharuskan peserta didik gemar membaca untuk menambah ilmu pengetahuan. Ekstra kullikuler dalam bidang akademik meliputi Science club dan English club.

Kecakapan hidup yang kedua dalam ekstrakulikuler adalah kesenian, kegitan ini merupakan upaya sekolah memfasilitasi peserta didik dalam mengapresiasi dalam bentuk seni sebagai bentuk nilai atau kultur sebagai bangsa. Ada beberapa jenis ektrakulikuler yang diajarkan diantaranya qiro'atul Quran yang mencerminkann nilai religius peserta didik. Musik/band, marching band dan tari yang melambangkan kreatifitas, semangat kebangsaan dan cinta tanah air pada diri peserta didik.

Yang ketiga adalah kecakapan olahraga yang membutuhkan kekuatan fisik dan semangat untu mendapatkan hasil maksimal. Kegiatan ekstrakulikuler olahraga ini pula membutuhkan kerjasama antara satu pemain dengan lainya. Nilai-nilai karakter yang didapatkan adalah disiplin, bekerja keras, gotong royong dan berintegritas tinggi. Ekstra kulikuler yang diajarkan adalah futsal dan basket. Dan ketrampilan merupakan kecakapan yang terakhir diajarkan pada ekstraklikuler. Kecakapan ini membutuhkan kesabaran serta keuletan dalam melakukan dan meyelesaikan tugas-tugasnya. Ekstrakulikuler yang diajarkan antara lain Hizbul 
Watahan atau kepanduan, seni bele diri Tapak Suci, Palang Merah Remaja dan PASKIBRA (Pasukan Pengibar Bendera). Karakter yang dapat diambil dari kegiatan ekstrakulikuler tersebut adalah disiplin, kerja keras, kreatif, madiri, semangat kebangsaan, cita tanah air, peduli lingkungan dan sosial, bertanggung jawab, nasionalis gotong royong dan berintegritas.

3. Pembiasaan dan Program Karakter

Penguatan karakter yang dilakukan oleh sekolah yang terkahir yaitu dengan melaksnakan kegiatan pembiasaan dan program karakter. Kegiatan pembiasaan adalah program yang dilakukan setiap hari dengan jadwal yang telah ditentukan dan didampingi oleh guru pembimbing dalam setiap kegiatan yang dilaksanakan. Kegiatan pembiasaan ini lebih bersifat religius dengan mengadakan sholat dhuha setiap pagi, sholat wajib berjamah disekolah serta pembiasaan-pembiasaan hidup secara islami. Namun peminasaan religius tersebut tidak terlepas dengan penanaman karakter yang terus diajarkan seperti kedisiplinan dan nilai kemandirian ketika melaksanakan shalat. Tidak lupa pula pembiasaan nilai karakter nasionali dengan melaksanakan upacara bendera setiap hari senin dan peringatan hari kemerdekaan. Serta pembiasaan toleransi dan goting royong melalui penerapan lima S (senyum, salam, sapa, sopan dan santun).

Sedangkan penguatan karakter melalui kegiatan terprogram terlaksana sesuai dengan program kerja yang telah di canangkan sekolah. Contoh program-program yang di siapkan adalah SICB (Student Islamic Character Building), Mubaligh Hijrah serta perkemahan dan out bound karakter. SICB merupakan salah satu program unggulan sekolah yang memiliki tujuan sebagai peningkatan karakter peserta didik dengan melaksanakan kegiatan menitipkan siswa dan siswi kelas 9 di pondok pesantren dengan maksud mampu membuka wawasan peserta didik tentang arti dari kehidupan sosial ketika bermasyrakat dan melatih kemandirian siswa ketika harus berpisah dengan orang tua selama tujuh hari. Dan tidak lupa pla memasukan nilai religiusitas dan gotong royong bersama dengan teman ketika jauh dari orang tua.

Sejalan dengan itu penerapan program karakter tidak hanya untuk kelas sembilan di jenjang akhir akan tetapi sejak awal telah dikenalkan dengan kegiatan Mubaligh Hijrah yaitu kegiatan religius yang dibalut dengan kepedulian lingkungan sosial serta gotong royong. Kegitan ini diperuntukan siswa tingkat awal dan 
menengah dengan menerjunkan peserta didik ke masjid sekitar untuk data berinteraksi dengan masyarkat sekitar ketika shoalt berjamaah. Selain itu kegiatan tersebut memberikann kesempatan peserta didik untuk bertemu dan berbagi bersama dengan siswa TPQ dengan mengajarkan mengaji dan kemudian ditutup dengan pembagian bingkisan kepada masyrakat sekitar.

Program karakter yang terkahir adalah perkemaan dan out bond karakter. Kegitan ini diselenggarakan bagi siswa tingkat awal sebagai upaya pengenalan program karakter sekolah. Program ini tidak dapat terepas dari nilai-nilai karakter yang dibangun seperti religius, nasionalisme, kemandirian, gorong royong dan integritas.

\section{KESIMPULAN}

Penguatan karakter adalah prioritas utama bagi seluruh lembaga pendidikan tidak terkecuali SMP Muhammadiyah 2 Taman. Karakter-karakter yang dibangun adalah karakter yang berlandaskan agama dan yang telah ditentukan oelh pemerintah. Karakter yang ada pada agama Islam adalah perbuatan atau prilaku yang dtentukan alam Al-Quran dan Hadist serta yang telah dicontohkan oleh Nabi Muhammad SAW. Sedangkan karakter yang telah ditentukan oleh pemerintah merupakan 18 nilai yang ada dalam masyarakat dan dikelompkan menjadi lima yaitu religiusitas, nasionalime, kemandirian, gotong royong, dan integritas. Nilai-nilai tersebut harus ditanamkan kepada peserta didik di sekkolah melalui pengintergrasian antara intrakulikuler, kokulikuler dan ekstrakulikuler.

Penguatan karakter melalui intrakulikuler dapat dilakukan dengan penyiapan materi dan model pembelajaran yang disandingkan dengan nilai karakter yang akan diberikan. Sedangkan penguatan karakter melalui kokulikuler dapat dimasukan kedalam mata pelajaran muatan lokal yang ada di sekolah. SMP Muhammadiyah 2 Taman menambahakan mata pelajaran bahasa daerah, Baca Tulis Al-Quran, ISMUBA dan Student Islamic Lesson sebagai upaya memasukan penguatan karakternya. Tidak lupa pula menambahkan pada kegiatan ekstrakulikuler dan program pembiasaan yang ada di sekolah untuk lebih memperkuat upaya penguatan karakter. 
Muhammad Arif Syaifuddin, Eni Fariyatul Fahyuni

\section{DAFTAR PUSTAKA}

Abdul Karim, Islam Nusantara (Yogyakarta: Gama Media, 2013)

Abdullah Idi, Pengembangan Kurikulum: Teori Dan Praktik (Jakarta: Gaya Media Pratama, 1999), p. 188

Anshori, Isa, Universitas Islam, Negeri Sunan, Ampel Surabaya, Jl Ahmad, Yani No, and others, 'Penguatan Pendidikan Karakter Di Madrasah Isa Anshori Universitas Islam Negeri Sunan Ampel Surabaya. Jl. Ahmad Yani No.117. Jemur Wonosari. Surabaya', 1.2 (2017), 63-74 $<$ https://doi.org/10.21070/halaqa.v1i2.1243>

Hamalik, Oemar, Dasar-Dasar Pengembangan Kurikulum (Bandung: Remaja Rosdakarya, 2007), p. 266

Kemendiknas, Pengembangan Pendidikan Budaya Dan Karakter Bangsa Pedoman Sekolah (Jakarta: Pusat Kurikulum Balitbang, 2010), p. 4

Majelis Pendidikan Dasar dan Menengah Pimpinan Pusat Muhammadiyah, Kurikulum Pendidikan Al-Islam, Kemubammadiyahan Dan Bahasa Arab (ISMUBA) (Jakarta, 20017)

Mappiare, Andi, Psikologi Remaja (Surabaya: Usaha Nasional Surabaya, 1982)

Mugiarso, Heru, Bimbingan Dan Konseling (Semarang: Unnes Press, 2011)

Mulyasa, E, Kurikulum Tingkat Satuan Pendidikan: Sebuah Panduan Praktis (Bandung: Remaja Rosdakarya, 2009)

Nana Syaodih Sukmadinata, Metode Penelitian Pendidikan (Bandung: Remaja Rosdakarya, 2005), p. 28

Pusat Kurukulum, Balitbang Depdiknas, Model Pengembangan Pelajaran Muatan Lokal SD/MI/SDLB-SMP/MTS-SMPLB-SMA/MA/SMALB/SMK Jakarta: Depdiknas, 2007)

Tadkirotun Musfiroh, Cerdas Melalui Bermain (Jakarta: Grafindo, 2008), p. 27

Yahya Khan, Pendidikan Karakter Berbasis Potensi Diri : Mendongkrak Kualitas Pendidikan (Yogyakarta: Pelangi Publishing, 2010), p. 4 